\title{
EFEKTIVITAS KEBIJAKAN STRATEGI PENGENDALIAN WABAH FLU BURUNG DI PROPINSI D.I. YOGYAKARTA, INDONESIA
}

\section{EFFECTIVENESS OF POLICY ON CONTROLLING STRATEGY OF AVIAN INFLUENZA OUTBREAKS IN D. I. YOGYAKARTA PROVINCE, INDONESIA}

\author{
R. Ahmad Romadhoni Surya Putra* dan F. Trisakti Haryadi \\ Fakultas Peternakan, Universitas Gadjah Mada, Jl. Fauna No. 3, Bulaksumur, Yogyakarta, 55281
}

\section{INTISARI}

\begin{abstract}
Wabah flu burung (AI) merebak di Indonesia mulai tahun 2004. Departemen Pertanian telah menerbitkan kebijakan mengenai program pengendalian AI. Program tersebut adalah sembilan (9) langkah pengendalian AI, program ini terdiri dari 9 langkah untuk melindungi peternak dari bahaya wabah AI. Tahun 2007, AI masih terjadi dan peternak mengalami kerugian hingga 33 milyar pada bulan Januari hingga April. Tujuan dari penelitian adalah mengetahui implementasi kebijakan strategi pencegahan flu burung dan efektivitas kebijakan dalam rangka mencegah penyebaran flu burung di tingkat peternak. Penelitian dilakukan menggunakan survei pada responden sampel yang diambil secara purposif. Berdasarkan pada analysis maka dapat disimpulkan bahwa: pertama, pelaksanaan kebijakan pengendalian AI ini perlu adanya pembenahan dari pihak-pihak yang terkait. Kedua, program pengendalian ini tidak efektif karena implementasinya hanya mencapai $45,22 \%$ dari seluruh langkah yang telah ditetapkan.
\end{abstract}

(Kata kunci: Flu burung, Pelaksanaan kebijakan, Efektivitas)

\section{ABSTRACT}

Indonesia encountered Avian Influenza (AI) outbreaks in 2004. Ministry of Agriculture had issued a policy as a program to control AI. It was defined as 9 (nine) steps of AI controlling strategy because there were 9 (nine) items to protect farmer from damaged. But, in 2007, AI was still happened and farmer lost their investment up to 33 billion from January to April. The objective of this study was to investigate the implementation and effectiveness of the policy of AI controlling strategy at the farmers' level. Purposive sampling was applied to select respondents. Two main results were obtained. Based on the analysis, it can be concluded that: first, the implementation of the policy program needed some improvement. Second, the effectiveness of the policy program was $45.22 \%$ from items of the program.

(Keywords: Avian influenza, Policy implementation, Effectiveness)

\section{Pendahuluan}

Penyebaran virus Avian Influenza (AI) di Indonesia semakin berdampak pada tingkat produksi produk-produk yang dihasilkan oleh peternakan ayam. Produksi daging ayam broiler di D. I. Yogyakarta pada tahun 2002 hingga 2006 terus menurun yaitu 20.994 ton, 19.115 ton, 18.561 ton, 14.997 ton, 15.147 ton (Anonimus, 2007). Kondisi ini tentunya sangat berkaitan erat dengan tingkat konsumsi masyarakat akan daging maupun telur. Penurunan ini memang belum tentu diakibatkan oleh adanya isu flu burung, akan tetapi persepsi sosial masyarakat bahwa flu burung dapat mengakibatkan kematian pada manusia mengakibatkan ketakutan masyarakat untuk mengkonsumsi

\footnotetext{
*Korespondensi (corresponding author):

Telp.+62 8170428 119, E-mail: rars.putra@gmail.com
}

produk-produk dari ayam (Putra, 2007). Hal ini menunjukkan bahwa dampak terjadinya wabah flu burung di Indonesia belum dapat teratasi dengan baik hingga saat ini.

Wabah flu burung sebenarnya telah mendapatkan perhatian dari pemerintah. Hal ini dapat dibuktikan dengan turunnya peraturan presiden nomor 7 tahun 2006 tentang pembentukan Komite Nasional Pengendalian Flu Burung (KNPFB). Proses ini sebenarnya telah didahului dengan terbitnya SK Dirjen Peternakan yang mengatur di wilayah budidaya ayam ras. Menurut SK Dirjen No. 17 tahun 2004 telah dinyatakan bahwa prioritas nasional untuk pengendalian wabah flu burung adalah dengan sembilan strategi pengendalian AI yaitu: 1) peningkatan biosekuriti, 2) vaksinasi daerah tertular dan tersangka, 3) depopulasi terbatas dan kompensasi, 4) pengendalian lalu-lintas unggas dan produknya, 5) surveilans dan penelusuran 
kembali, 6) pengisian kandang kembali, 7) stamping out di daerah tertular baru, 8) public awareness, dan 9) monitoring dan evaluasi (Anonimus, 2004).

Kasus AI masuk di DIY sejak awal 2004 (Muzayyanah, 2005). Hal ini juga ditegaskan dalam Keputusan Menteri Pertanian Nomor : 338.1/Kpts/PD.620/9/2005 bahwa Daerah Istimewa Yogyakarta (DIY) telah dinyatakan sebagai salah satu daerah yang terjangkit wabah AI (Anonimus, 2005). Berdasarkan keputusan menteri tersebut maka DI. Yogyakarta merupakan wilayah yang harus menerapkan pola dan langkah-langkah dalam penanggulangan wabah AI. Sesuai dengan kondisi tersebut maka perlu dilakukan penelitian sebagai evaluasi terhadap efektivitas pelaksanaan kebijakan pemerintah tentang sembilan langkah strategi pengendalian AI di DIY.

Penelitian tentang evaluasi pelaksanaan kebijakan penanggulangan flu burung ini belum pernah dilakukan. Penelitian terakhir adalah tentang dampak ekonomi dari wabah flu burung di Jawa. Hasil penelitian tersebut menyebutkan bahwa peternak ayam di Jawa mengalami penurunan laba sebesar Rp. 9.150.000,00 hingga Rp. 438.040.000,00/bulan untuk ayam petelur, $\mathrm{Rp}$. 9.350.000,00 hingga Rp. 429.860.000,00/bulan untuk ayam pedaging, dan Rp. 380.000,00 hingga Rp. 286.920.000,00/bulan untuk ayam buras, itik, serta puyuh (Sumiarto et al., 2006). Penelitian tersebut menunjukkan bahwa langkah-langkah pengendalian flu burung belum efektif dilaksanakan.

Penelitian tentang efektivitas pelaksanaan kebijakan strategi penganggulangan AI ini bertujuan untuk mengetahui: 1) implementasi kebijakan strategi pencegahan flu burung ditingkat peternak, dan 2) efektivitas kebijakan dalam rangka mencegah penyebaran flu burung di tingkat peternak.

\section{Metode Penelitian}

Metode survei diterapkan pada penelitian ini dengan menggunakan alat bantu berupa kuesioner. Selain itu juga dilakukan wawancara (in-depth interview) kepada peternak unggas dan petugas lapangan yang terkait dengan kebijakan tersebut. Responden yang dipilih sebagai sampel dalam penelitian ini diambil secara purposif sebanyak 100 peternak. Persyaratan yang ditetapkan bagi responden adalah peternak unggas, khususnya ayam kampung, di daerah yang pernah terkena terkena wabah AI di DIY.

\section{Hasil dan Pembahasan}

Usaha peternakan ayam kampung secara umum merupakan usaha sampingan. Tujuan memelihara unggas bermacam-macam diantaranya adalah sebagai hobby, konsumsi rumah tangga, tabungan, persiapan biaya sekolah, sumbangan untuk hajatan, dan persiapan kebutuhan mendadak lain. Skala usaha juga tidak dapat dikategorikan sebagai usaha komersial. Rerata kepemilikan unggas disajikan pada Tabel 1.

Rerata kepemilikan unggas pada saat belum terkena wabah adalah 29 ekor tiap responden (Tabel 1). Pendapatan rerata per bulan yang diperoleh dari usaha unggas ini sebesar Rp. 75.000,00 (Tabel 2). Pada saat terkena wabah AI terjadi penurunan tingkat kepemilikan unggas sekitar $80,87 \%$. Rerata kepemilikan saat terkena wabah AI adalah 6 ekor unggas tiap responden (Tabel 1). Penurunan yang cukup drastis ini juga diikuti dengan kerugian yang cukup besar yaitu mencapai Rp. 585.000,00 (Tabel 2). Pada saat sesudah terkena wabah atau pada saat data diambil, rerata tingkat pemeliharaan unggas telah meningkat sebesar $26,63 \%$ menjadi 7 ekor unggas pada tiap responden (Tabel 2). Kenaikan tingkat pemeliharaan memang belum bisa mencapai jumlah skala kepemilikan hingga sebelum terkena wabah AI, akan tetapi kondisi ini memperlihatkan bahwa dalam tempo yang cukup singkat peternak telah berusaha untuk kembali memelihara unggas.

\section{Implementasi kebijakan pengendalian AI}

Adanya peningkatan skala kepemilikan hingga 26,63\% membuktikan bahwa kebijakan pengendalian AI berupa sembilan langkah strategi penanggulangan AI telah diimplementasikan. Kasus AI bulan Juli 2007 dijadikan patokan oleh petugas lapangan dari pihak pemerintah. Hal ini merupakan salah satu bukti bahwa peternak memiliki kepedulian terhadap kasus AI (public awareness) dalam arti kasus ini tidak dianggap sebagai kasus penyakit ternak biasa. Kejadian tersebut kemudian ditindaklanjuti dengan proses pengecekan oleh petugas (monitoring dan evaluasi).

Tabel 1. Rerata kepemilikan unggas (poultry ownership average)

\begin{tabular}{lc}
\hline \hline \multicolumn{1}{c}{ Parameter (parameters) } & Rerata kepemilikan unggas (ekor) (poultry ownership \\
average (head))
\end{tabular}


Tabel 2. Rerata pendapatan dan kerugian responden (average and loss of respondents' income)

\begin{tabular}{lc}
\hline \hline \multicolumn{1}{c}{ Parameter (parameters) } & Jumlah (Rp) (amount (Rp)) \\
\hline Pendapatan total per bulan (income per month) & $502.000,00$ \\
Pendapatan dari unggas per bulan (income per month from poultry) & $75.000,00$ \\
Kerugian akibat wabah AI (loss caused by AI outbreaks) & $585.000,00$ \\
\hline
\end{tabular}

Menurut responden yang bertugas di lapangan, kejadian AI di DIY bukan sesuatu yang asing lagi. Hampir seluruh wilayah di DIY telah terkena AI sejak rentang waktu dari tahun 2004 hingga 2009. Lokasi-lokasi yang terkonfirmasi positif AI (bulan Juli 2007) beberapa diantaranya telah terkena di tahun-tahun sebelumnya atau minimal dusun sekitarnya pernah dinyatakan terserang wabah AI (surveilance). Dari penelusuran riwayat wabah AI didapatkan fakta bahwa ketika dinyatakan positif terserang wabah AI, para peternak keberatan untuk dilakukan depopulasi terbatas akibat dari nilai kompensasi yang dianggap tidak sepadan dengan harga ternak (depopulasi terbatas), akan tetapi pemerintah tetap melakukan stamping out untuk daerah tertular baru sebagai sarana untuk pencegahan agar tidak menyebar ke daerah lain (stamping out). Kedua hal ini sebenarnya tidak merugikan bagi peternak sebab pada dasarnya penyebaran virus AI ini sangat cepat dalam menginfeksi unggas. Paling tidak dalam satu dusun, mayoritas unggas dari populasi yang ada akan tertular virus ini bahkan mati.

Para peternak yang unggas piaraannya maupun yang di wilayah sekitarnya pernah terserang wabah AI hanya mengandalkan pencegahan dengan cara menjaga kebersihan kandang dan melakukan biosekuriti (peningkatan biosekuriti). Akan tetapi cara ini menurut mereka tidak cukup efisien sebab mereka harus mengeluarkan biaya lebih banyak untuk pembuatan kandang dan pembelian peralatan. Padahal dengan jumlah piaraan rerata hanya 28,85 ekor akan lebih menguntungkan bagi peternak untuk memelihara dengan cara diumbar. Akibatnya beberapa peternak tetap pada kebiasaan pemeliharaan konvensional dengan cara mengumbar ternaknya. Cara ini sangat menyulitkan dalam melakukan vaksinasi AI yang dilakukan oleh petugas lapangan. Vaksin yang selama ini dibagikan gratis oleh pihak pemerintah tidak cukup efektif menjangkau peternak. Hal ini setidaknya disebabkan oleh dua hal yaitu sistem pemeliharaan yang belum dikandangkan dan kekurangan sumber daya manusia petugas lapangan yang bertugas sebagai vaksinator.

Pengendalian lalu lintas ternak unggas sebagai tanggung jawab pemerintah telah dilaksanakan terutama untuk mengawasi pasar-pasar unggas dan unggas-unggas yang berasal dari daerah ter- tular. Kondisi ini menurut para peternak tidak cukup meyakinkan sebab banyak unggas yang dijual langsung pada konsumen tanpa melewati pasar unggas. Fakta yang ada juga memperlihatkan bahwa pos-pos lalu lintas ternak yang biasanya berada di wilayah perbatasan, kondisinya tidak cukup memadai untuk melakukan pengendalian dan pengawasan lalu lintas ternak.

Bagi para peternak, keberadaan unggas terutama ayam kampung sangat penting bagi keberlangsungan rumah tangga. Walaupun peternak banyak menyatakan bahwa usaha ini adalah usaha sampingan, namun peran unggas khususnya ayam kampung cukup penting terutama untuk memenuhi kebutuhan-kebutuhan mendadak dan insidental. Kondisi ini menyebabkan mereka tetap berusaha memelihara unggas walapun sebagian besar masih trauma dengan kerugian yang harus ditanggung akibat terserang wabah AI (restocking). Hal ini dibuktikan dengan peningkatan kepemilikan ternak yang mencapai $26,63 \%$ dari sejak terserang wabah. Peningkatan unggas piaraan setelah wabah sangat terkait dengan intervensi pemerintah melalui kebijakan-kebijakannya. Menurut penelitian Sumiarto et al. (2006), biaya yang dikeluarkan oleh pemerintah DIY untuk pengendalian AI mencapai Rp. 719.000.000,00 per tahun. Hal itu tentunya akan menjadi lebih baik jika kebijakan dilaksanakan secara efektif.

\section{Efektivitas pelaksanaan kebijakan pengendalian} AI

Strategi pengendalian AI berdasarkan SK Dirjen No. 17 tahun 2004 yang diturunkan dalam bentuk program pengendalian berupa sembilan langkah strategi pengendalian dengan cara: 1) peningkatan biosekuriti, 2) vaksinasi daerah tertular dan tersangka, 3) depopulasi terbatas dan kompensasi, 4) pengendalian lalu-lintas unggas dan produknya, 5) surveilans dan penelusuran kembali, 6) pengisian kandang kembali, 7) stamping out di daerah tertular baru, 8) public awareness, dan 9) monitoring dan evaluasi, pada dasarnya telah dilakukan. Implikasi kebijakan secara minimal telah mampu mengembalikan kemauan untuk beternak kembali, akan tetapi perlu kiranya untuk diketahui mengenai efektivitas dari program pengendalian tersebut. 
Data di lapangan menunjukkan bahwa dari sembilan langkah strategi pengendalian AI, rerata para peternak hanya mampu merealisasikan kurang dari $50 \%$. Persebaran pelaksanaan kebijakan tersebut oleh peternak disajikan pada Tabel 3 .

Dari Tabel 3 dapat dilihat bahwa program pengendalian AI di DIY yang mampu dilaksanakan oleh peternak mencapai $45,22 \%$ dari total sembilan langkah yang ditetapkan melalui SK Dirjen No 17 tahun 2004. Berdasarkan fakta di lapangan para peternak mengaku hanya mampu melaksanakan sekitar 4 hingga 5 program saja dari sembilan yang dicanangkan. Hal ini disebabkan karena beberapa langkah tidak terkait dengan peternak akan tetapi lebih merupakan tugas pemangku kebijakan. Fakta ini lebih besar dari perkiraan para petugas lapangan dari pihak pemerintah yang hanya memperkirakan 3 hingga 4 yang mampu dilaksanakan. Hal ini sangat tidak efektif jika dibandingkan dengan pendapat Honhold et al. (2004) yang menyatakan bahwa sebuah program pengendalian penyakit ternak akan efektif mencapai tingkat keberhasilan jika 99,99\% program terlaksana dengan baik. Fakta lain dari Sumiarto et al. (2006) menyatakan bahwa efektivitas pelaksanaan kebijakan strategi pengendalian flu burung oleh Dinas Peternakan di Jawa mencapai $88,9 \%$, lebih lanjut juga diungkapkan bahwa hal ini belum efektif karena belum mencapai 99,99\%.

Dari Tabel 4 dapat diketahui bahwa skor berdasarkan respon dari responden berkisar antara 2,8 hingga 3,8. Semakin besar skor tersebut menunjukkan bahwa item strategi program pengendalian tersebut semakin rutin dilakukan, sebaliknya jika skor semakin kecil maka program tersebut semakin tidak pernah dilakukan. Untuk skor di atas 3 maka dapat dipastikan bahwa kegiatan strategi tersebut dilaksanakan oleh peternak, skor sama dengan 3 dan di bawahnya mencerminkan bahwa kegiatan tersebut hampir tidak pernah dilakukan oleh responden. Skor tertinggi $(3,8)$ adalah untuk melakukan public awareness (Tabel 4). Hal ini sangat mungkin dilakukan karena hanya menuntut para peternak untuk selalu waspada terhadap penyebaran AI. Skor terendah $(2,8)$ adalah untuk melakukan depopulasi terbatas dan kompensasi (Tabel 4). Kegiatan ini paling jarang dilakukan oleh peternak karena wabah AI biasanya menyerang semua ternak yang dimiliki sehingga sudah mati sebelum dilakukan depopulasi. Kompensasi yang diberikan juga tidak seimbang dengan harga ternak sehingga sisa ternak yang selamat dari AI langsung dijual ke pasar atau dipelihara kembali.

Berdasarkan urutan skor tersebut dapat diketahui kegiatan yang dilakukan oleh peternak dalam melakukan pengendalian wabah AI yang didasarkan pada sembilan langkah strategi pengendalian AI yaitu sebagai berikut: 1) public awareness, 2) pengendalian lalu-lintas unggas dan produknya, 3) peningkatan biosekuriti, 4) pengisian kandang kembali, dan 5) stamping out di daerah tertular baru.

Urutan tersebut dapat dijadikan evaluasi dalam rangka pengambilan kebijakan pengendalian AI yang efektif. Berdasarkan wawancara dengan petugas lapangan dari pemerintah, sembilan langkah yang harus dilakukan adalah sangat berat untuk

Tabel 3. Persentase pelaksanaan kebijakan pengendalian AI (percentage of AI controll policy's implementation)

\begin{tabular}{ccc}
\hline \hline $\begin{array}{c}\text { Pelaksanaan program pengendalian (\%) } \\
(\text { program implementation (\%)) }\end{array}$ & Jumlah (orang) (number (person)) & Persentase (\%) (percentage (\%)) \\
\hline$<16,96$ & 18 & 18,00 \\
$16,96-73,48$ & 61 & 61,00 \\
$73,48-100,00$ & 21 & 21,00 \\
Total (total) & 100 & 100,00 \\
\hline Rerata (average) & & 45,22 \\
\hline
\end{tabular}

Tabel 4. Skor untuk tiap-tiap item sembilan langkah pengendalian AI (nine steps controlling AI score)

\begin{tabular}{lc}
\hline \hline \multicolumn{1}{c}{ Item } & Skor (score) \\
\hline Peningkatan biosekuriti (biosecurity improvement) & 3,2 \\
Vaksinasi daerah tertular dan tersangka (vaccination) & 2,9 \\
Depopulasi terbatas dan kompensasi (depopulation) & 2,8 \\
Pengendalian lalu-lintas unggas dan produknya (poultry distribution management) & 3,5 \\
Surveilans dan penelusuran kembali (surveillance) & 2,9 \\
Pengisian kandang kembali (restocking) & 3,2 \\
Stamping out di daerah tertular baru (stamping out) & 3,2 \\
Public awareness & 3,8 \\
Monitoring dan evaluasi (monitoring and evaluation) & 3,0 \\
\hline
\end{tabular}


direalisasikan terutama untuk peternakan unggas sektor 3 dan 4. Akan lebih baik jika strategi pengendalian tersebut dapat disederhanakan sehingga mampu dilaksanakan secara sempurna baik oleh peternak maupun petugas lapangan.

\section{Kesimpulan dan Saran}

\section{Kesimpulan}

Implementasi kebijakan pengendalian penyebaran wabah flu burung di tingkat peternak melalui program sembilan langkah strategi pengendalian AI masih memerlukan pembenahan dari pihak pihak terkait. Hal ini dikaitkan dengan kebingungan di tingkat peternak mengenai langkahlangkah yang harus mereka lakukan. Temuan di lapangan membuktikan bahwa kebijakan sembilan langkah strategi pengendalian AI tersebut belum secara jelas mengatur mengenai subyek yang harus melaksanakan. Peternak khususnya di sektor 3 dan 4 serta petugas lapangan dari pihak pemerintah masih kebingungan untuk memilah dari sembilan langkah tersebut yang menjadi tanggung jawabnya.

Pelaksanaan kebijakan program pengendalian flu burung di DIY khususnya pada sektor 3 dan 4 belum berhasil dilaksanakan secara efektif. Program yang mencangkup sembilan item langkah pengendalian AI tersebut hanya dapat dilaksanakan secara total sebesar $45,22 \%$ oleh peternak. Program pengendalian penyakit ternak bisa dikatakan efektif jika 99,99\% program dilaksanakan.

\section{Saran}

Intervensi pemerintah dalam pengendalian AI mutlak diperlukan. Untuk itu perlu disusun kebijakan yang sederhana dan mudah untuk diimplementasikan di lapangan. Kebijakan tersebut juga harus jelas ditujukkan kepada subyek atau obyek tertentu sehingga tidak timbul kerancuan pada tahap pelaksanaan. Harapannya kebijakan tersebut dapat dilaksanakan secara efektif dan efisien untuk mengendalikan wabah AI maupun penyakit-penyakit ternak yang lain.

Perlu penyederhanaan terhadap langkahlangkah pengendalian AI. Fakta yang didapat menunjukkan bahwa hanya $45,22 \%$ dari sembilan langkah saja yang mampu dilaksanakan maka pemerintah perlu mengkaji kembali strategi pengendalian tersebut dan menyusutkan menjadi 4 sampai 5 program sehingga dapat dilaksanakan secara efektif. Program-program tersebut adalah public awareness, pengendalian lalu-lintas unggas dan produknya, peningkatan biosekuriti, stamping out, restocking, monitoring dan evaluasi.

\section{Ucapan Terima Kasih}

Kami mengucapkan terima kasih kepada LPPM UGM yang telah memberikan hibah penelitian untuk dosen muda UGM tahun 2007, dan kepada rekan-rekan mahasiswa yang membantu penelitian ini dari awal sampai akhir.

\section{Daftar Pustaka}

Anonimus. 2004. Arah Kebijakan Pemerintah Pusat Dalam Program Penanggulangan Wabah AI di Indonesia. Available at http://www.litbang. deptan.go.id. Accession date: 27 Maret, 2007.

Anonimus. 2005. Telur Memukau, Broiler Masih Terpuruk. Available at http://www.pinsar. com. Accession date: 29 Maret, 2007.

Anonimus. 2007. Statistik Peternakan 2006. Direktorat Jendral Peternakan. Departemen Pertanian. Jakarta.

Honhold, N., N.M. Taylor, A. Wingfield, P. Einshoi, C. Middlemiss, L. Eppink, R. Wroth, and L.M. Mansley. 2004. Evaluation of application of veterinary judgement in the pre-emptive cull of contiguous primises during epidemic of foot-and-mouth disease in Cumbria in 2001. The Vet. Rec. 155: 349355.

Muzayyanah, M.A.U. 2005. Keseimbangan pasar komoditas daging ayam di Daerah Istimewa Yogyakarta. Laporan Penelitian. Fakultas Peternakan UGM. Yogyakarta.

Putra, R.A.R.S. 2007. Persepsi masyarakat tentang flu burung (Avian Influenza). Laporan Penelitian. Fakultas Peternakan UGM. Yogyakarta.

Sumiarto, B., K.A. Santosa, H. Susetya, E.M.N. Setyawan, dan R.A.R.S. Putra. 2006. Analisa ekonomi program pengendalian Avian Influenza di Jawa. Laporan Penelitian. Fakultas Kedokteran Hewan UGM. Yogyakarta. 